\title{
Impact of resources and transformational leadership in thestrategic management of small business enterprises
}

\section{Impacto de los recursos y liderazgo transformacional en la gestión estratégica de las pequeñas empresas comerciales}

\author{
LEYVA-OSUNA, Beatriz Alicia $\uparrow$, JACOBO-HERNANDEZ, Carlos Armando* and AGUIRRE- \\ CHOIX, Ricardo
}

Instituto Tecnológico de Sonora, Departamento de Ciencias Administrativas. Calle 5 de Febrero 818, Centro, Urb. No. 1, 85000 Cd Obregón, Son.

ID $1^{\text {st }}$ Author: Beatriz Alicia, Leyva-Osuna / ORC ID: 0000-0003-4935-6326, Thomson ID: S-5836-2018, ID PubMed: beatrizleyva, CVU CONACYT ID: 285583

ID $1^{\text {st }}$ Coauthor: Carlos Armando, Jacobo-Hernández / ORC ID: 0000-0002-8524-6258, CVU CONACYT ID: 95324

ID $2^{\text {nd }}$ Coauthor: Ricardo, Aguirre-Choix / ORC ID: 0000-0001-6577-0979, CVU CONACYT ID: 624798

DOI: $10.35429 /$ EJRP.2019.8.5.10.19

Received January 15, 2019; Accepted June 25, 2019

\begin{abstract}
A study with a quantitative focus was carried out on 140 small companies in the commerce sector of Ciudad Obregón Sonora, which sought to achieve the objective of analyzing the impact of the company's resources and transformational leadership in the process of strategic management; which allowed an analysis of the strategic situation of these companies. For the scope of the objective, the process of the scientific method was used, where a 36-question instrument with six levels of Likert scale was applied, and the SMART-PLS Model, Structural Equations, was used for statistical analysis, where the Resources variable was observed to have a positive, direct and highly significant effect on the Strategic Management variable, on the other hand, Transformational Leadership has a positive and direct but not statistically significant effect on the Strategic Management variable, Strategic Management, (a.k.a. .218, p<-090 n.s.). This research concluded that the entrepreneur is unclear about his leadership and that when a strategy is formulated and executed efficiently through the correct allocation of resources at each stage of it, a successful situation is achieved in the company's strategy.
\end{abstract}

\begin{abstract}
Resumen
Se realizó un estudio con enfoque cuantitativo en 140 empresas pequeñas del sector comercio de Ciudad Obregón Sonora, en el cual se buscó alcanzar el objetivo deanalizar el impacto que tienen los recursos de la empresa y liderazgo transformacional en el proceso de la gestión estratégica; lo cual permitió hacer un análisis de la situación estratégica de estas empresas. Para el alcance del objetivo se utilizó el proceso del método científico, donde se aplicó un instrumento de 36 preguntas con seis niveles en escala de Likert, y se utilizó para el análisis estadístico el Modelo de SMART-PLS, Ecuaciones Estructurales, donde se observó que la variable de Recursos tienen un efecto positivo, directo y altamente significativo $(\beta .405$, $\mathrm{p}<=.000$ ), en la variable de Gestión Estratégica, por otro lado el Liderazgo Transformacional, tiene un efecto positivo y directo pero no significativo estadísticamente en la Gestión Estratégica, ( $\beta$.218, $\mathrm{p}<=090$ n.s.). En esta investigación se concluyó que el empresario no tiene claro su liderazgo y que cuando una estrategia se formula y ejecuta eficientemente a través de la asignación correcta de los recursos en cada etapa de la misma, se logra una situación de éxito en la estrategia de la empresa.
\end{abstract}

Estrategia, Liderazgo, Recursos ECORFAN Journal-Republic of Peru. 2019, 5-8: 10-19.

\footnotetext{
* Correspondence to Author (email: carlos.jacobo@itson.edu.mx)

$\uparrow$ Researcher contributing first author.
} 


\section{Introduction}

The constant exit of SMEs from their market, leads to study the phenomena that do not allow the advance and maturity of many of them and end up closing. According to INEGI (2015) the life expectancy for MSMEs is 7.8 years and this depends on factors such as poor quality, lack of good administrative management, brand, poor planning and low sales; Therefore, for the survival of MSMEs, it is important to develop a strategy and support mechanisms that focus on encouraging innovation and new business opportunities. (INADEM, 2018).

In Mexico, the most incident problems in SMEs during 2018, Arana (2018), describe them in the following areas, for example, their management $50 \%$ of entrepreneurs state that their growth is not fast and $66 \%$ mention not climbing to the next level, which is reflected in the lack of strategic plans and sales stagnation. Credit is also another factor by which companies do not grow, since 7 out of 10 entrepreneurs state that credit for SMEs is more expensive than the credit that it is granted to large companies, they must keep complicated tax accounting, they can generate a bad credit history as well as not having a good financial analysis; all this the application and good use of the credits. The attraction of Capital must be a strategic priority for the business. With this, entrepreneurs can refine their vision and long-term plans, with the experience and advice of investors.

\section{Problem Statement}

Currently, research in companies in Ciudad Obregón has been booming through universities, where it is about knowing the current situation of SMEs and supporting the improvement of companies with the results. This research stems from the impact of the closure of companies in our state of Sonora, the information provided by INEGI (2014), mentions that the average number of companies at birth is 8 years and this is as "a life expectancy". Among all the factors that can lead to the closure of a company, only in this study will the variables of Strategy Management, Transformational Leadership and Resources be analyzed.
Regarding the strategy issue in Ciudad Obregón, there is not enough information, so we will rely on the study of Leyva, Ochoa and Jacobo (2013), where results are obtained from 55 SMEs that were interviewed, and where 42 of them state that they formulate a strategy only, when they detect an opportunity $(45.45 \%)$ and with $(40 \%)$ the entrepreneurs who formulate the strategy is because they were presented with a problem. According to this information, the entrepreneur does not take as a priority the strategy to survive in his business, they continue working operatively, being up to date without managing their resources and implementing a strategy. The rest of the SMEs (13) do not carry out the strategy development activity.

It is important to study the aforementioned variables, because they allow us to reduce the closure of SMEs, through the scope of good performance since Strategy Management covers areas such as culture, structure, resources, systems, leadership, processes, and other functional and operational areas of SMEs. According to the exposed background, the research question is as follows: What is the impact of the company's Resources and Transformational Leadership of the manager in the Strategic Management of Commercial SMEs, in Ciudad Obregón, Sonora? And to answer this question the following objective is elaborated: to analyze the impact that the resources of the company and transformational leadership have in the process of the Strategic Management.

Each time an SME starts work, it becomes a hope for Mexico, as it is an option that allows it to cope with its economy, because they contribute their grain of sand to the reduction of the unemployment problem. It is clear that it is important to carry out projects that strengthen SMEs in their administration and operation since they begin their work, during their development and support in their survival. (Pro Mexico, 2013).

\section{Theoretical framework}

This section will discuss the variables of Strategic Management, Resources and Transformational Leadership, defining the variables and their dimensions to investigate. 
Fernández (2006), clarifies that Strategic Management develops competitive strategies, based on organizational policies and structures that allow the allocation of the resource to be favorable, for its success. So also David, (2008), mentions that the stages of formulation or design, implementation and evaluation of the strategy, is the main function of the variable Strategic Management, this allows to obtain the scope of the objectives set by the leader of the organization.

Below in table 1. The components of the Strategic Management variable are presented.

\begin{tabular}{|l|l|l|}
\hline $\begin{array}{c}\text { Information } \\
\text { Analysis and } \\
\text { Strategy } \\
\text { Design }\end{array}$ & \multicolumn{1}{c|}{$\begin{array}{c}\text { Strategy } \\
\text { implementation }\end{array}$} & \multicolumn{1}{c|}{$\begin{array}{c}\text { Strategy } \\
\text { Evaluation }\end{array}$} \\
\hline $\begin{array}{l}\text { SWOT } \\
\text { Analysis }\end{array}$ & $\begin{array}{l}\text { Company } \\
\text { structure }\end{array}$ & $\begin{array}{l}\text { Supervision } \\
\text { And } \\
\text { monitoring }\end{array}$ \\
\hline $\begin{array}{l}\text { Mission and } \\
\text { vision }\end{array}$ & Motivation & $\begin{array}{l}\text { Applications of } \\
\text { corrective } \\
\text { measures in the } \\
\text { process }\end{array}$ \\
\hline Goals & $\begin{array}{l}\text { Strategy } \\
\text { Communication }\end{array}$ & $\begin{array}{l}\text { Evaluation of } \\
\text { results }\end{array}$ \\
\hline Budget & $\begin{array}{l}\text { Changes in the } \\
\text { internal and } \\
\text { external factors of } \\
\text { the company }\end{array}$ & \\
\hline $\begin{array}{l}\text { Company } \\
\text { resources }\end{array}$ & $\begin{array}{l}\text { Employee skills } \\
\text { in the } \\
\text { implementation } \\
\text { of the strategy }\end{array}$ & \\
\hline Participation & \multicolumn{2}{|c|}{} \\
\hline
\end{tabular}

Table 1 Strategic Management and its Components Source: own elaboration adapted from Torres (2014). Strategic management.

For a company to develop its competitive advantage, it must first know the resources available to the company, and take advantage of them for the development and implementation of the strategy, thus improving its efficiency and effectiveness. According to Barney, 1991, cited by Arbelo \& Pérez, (2001), resources are classified into 1) Human resources, 2) Physical Resources, and 3) Organizational Resources.

Next in Table 2, the dimensions in which resources and capacities are divided are represented.

\begin{tabular}{|c|c|c|c|c|c|}
\hline $\begin{array}{l}\text { Physical } \\
\text { resources }\end{array}$ & $\begin{array}{l}\text { Financial } \\
\text { resources }\end{array}$ & $\begin{array}{c}\text { Organizational } \\
\text { Resourres }\end{array}$ & $\begin{array}{c}\text { Human } \\
\text { Resources and } \\
\text { Capabilitites }\end{array}$ & $\begin{array}{l}\text { Technological } \\
\text { Ressources and } \\
\text { Culture }\end{array}$ & $\begin{array}{c}\text { Commercial } \\
\text { Resources }\end{array}$ \\
\hline Installations & Budget & $\begin{array}{l}\text { Company } \\
\text { structure }\end{array}$ & Training & $\begin{array}{l}\text { Information } \\
\text { for decision } \\
\text { making }\end{array}$ & Market \\
\hline $\begin{array}{l}\text { Machinery } \\
\text { and } \\
\text { equipment }\end{array}$ & & & Abilities & Technology & Brand \\
\hline & & & \begin{tabular}{l|l} 
Motivation \\
Communication
\end{tabular} & Culture & \\
\hline
\end{tabular}

Table 2 Resources and their dimensions

Source: own elaboration adapted from Rubio and Aragón (2006) and Grant (2006) cited by Cardona (2013)

Below is presented in table 3 , the dimensions to study of transformational leadership and its breakdown.

Denro the issue of Transformational Leadership is mentioned as an example that is one that makes a transformation of breadth and depth is not only represented with a change, but that this change is very similar to a metamorphosis. (Burns, 2003). In other words, the leader valuablely transforms the worker by increasing his morale, stimulating his intelligence, increasing his motivation to propose and solve problems and give better performance in his work group.

\begin{tabular}{|c|c|c|}
\hline $\begin{array}{c}\text { Specific } \\
\text { characteristic } \\
\text { of the leader } \\
\text { during } \\
\text { strategy } \\
\text { development }\end{array}$ & $\begin{array}{c}\text { Specific } \\
\text { characteristic of } \\
\text { the leader } \\
\text { during the } \\
\text { implementation } \\
\text { of the strategy }\end{array}$ & $\begin{array}{c}\text { General } \\
\text { characteristics of the } \\
\text { leader during the } \\
\text { management } \\
\text { process }\end{array}$ \\
\hline \multirow[t]{6}{*}{ Flexibility } & Motivation & $\begin{array}{l}\text { Securities } \\
\text { Congruence }\end{array}$ \\
\hline & & Charisma \\
\hline & & $\begin{array}{l}\text { Individual } \\
\text { Consideration }\end{array}$ \\
\hline & & $\begin{array}{l}\text { Intellectual } \\
\text { stimulation }\end{array}$ \\
\hline & & Inspiration \\
\hline & & $\begin{array}{l}\text { Psychological } \\
\text { Tolerance } \\
\text { (sense of good } \\
\text { humor) }\end{array}$ \\
\hline
\end{tabular}

Table 3 Characteristics of the Transformational Leader and its dimensions

Source: own elaboration adapted from Bernal (2001) and Pedraja, Rodríguez, and Rodríguez (2006)

According to the theory and empirical works the theoretical model and the research hypotheses are the following: 


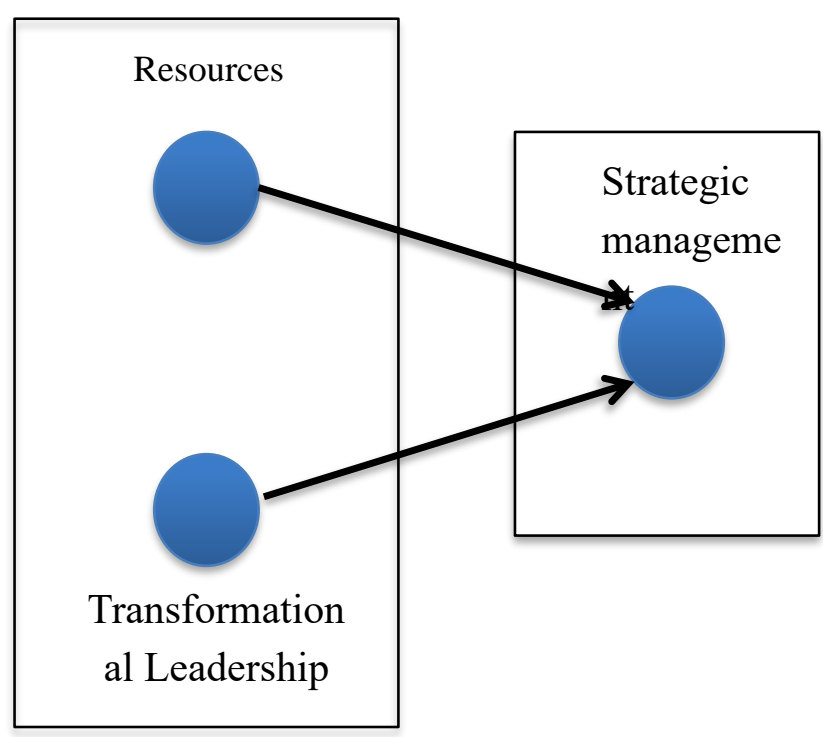

Figure 1 Theoretical model of the variables. Own elaboration

The research hypotheses according to the theoretical model are the following:

H1. Resources have a Positive and Direct effect on Strategic Management.

H2. Transformational Leadership has a Positive and Direct effect on Strategic Management.

These hypotheses will be checked through statistical analysis.

\section{Methodology}

The methodology used in this study, allows validating and giving reliability to the results of the research, so the strategy to follow proposed by Bernal (2010) is as follows:

This research uses the scientific method with a quantitative approach, this approach includes models of structural equations that allow to show causal paths in the investigation. (Creswell, 2003). Thus, this research is also considered correlational since it allows to determine the statistical relationships between the study variables. (Tamayo, 2004). The hypothesis test will be carried out with the PLS statistical method, so the research will also be based on the explanatory method, since the hypothesis test is intended to explain things, phenomena or facts. (Bernal, 2006). Finally, the research design is NOT experimental and Transactional, the data is collected in a single moment without manipulation. (Toro \& Parra, 2006).
An instrument was developed which allowed to obtain information regarding the variables to study which will help the acceptance or rejection of the hypotheses raised. The structured questionnaire consists of 36 questions, which is divided into four sections, which are: 1) General data of the interviewee, 2) strategic management section, 3) resources section, 4) transformational leadership section.

The measuring instrument is focused to be answered by people with the highest hierarchy in the company, or be the person who can make important decisions in the company. Through the six-level Likert scale, the questionnaire questions will be measured. The advantage on this scale is that it helps the answers do not match in the centralism (Rositas, 2014).

The validation of the instrument, with respect to its format, to the questions that constitute the study variables and their dimensions; This validation is carried out through five experts in the field of research through a questionnaire with a Likert scale from 1 to 4, adapted from (Segovia, 2014).

This also measured reliability through a pilot test of 60 companies that make up the population of Small businesses in Ciudad Obregón. The calculations of the chronbach alpha for reliability are obtained from the Statistical Package SPSS version 21 and the data of the companies were taken from the list of (INEGI-DENUE, 2012).

The companies under study are the small commercial companies of Ciudad Obregón, Sonora, which according to the Official Gazette of the Federation (2013) mentions that small commercial companies are those that range from 11 to 30 employees. The population of these companies is obtained from INEGI-DENUE (2012) obtaining a total of 258 commercial companies in Ciudad Obregón. 
The calculation of the sample strongly impacts the results of statistical significance, with respect to structural equations there is not so much robustness in the sample, but according to Hair, Anderson, Tatham and Black (1999), the recommended samples can range from 100 to 200 units The sample obtained for this research is 140 companies, according to the golden rule according to Barclay, Higgins and Thompson (1995), cited by Hair, Hult, Ringle and Sarstedt, (2017), where it is indicated that the sample is obtained to multiply 10 times the largest number of training indicators (items) of the same construct; In this study, the Strategic Management variable is the one with the highest Items 14 in its total, so the sample is 140 companies to be surveyed. The method to analyze the statistical results of the hypotheses will be through the SMART-PLS software (Structural Equations).

\section{Results}

This section presents the statistical analysis of the information that was collected from the small commercial companies of Ciudad Obregón, Son. Within the results, the alphas obtained from the pilot test are presented.

\begin{tabular}{|l|r|r|r|}
\hline \multicolumn{1}{|c}{ Construct } & \multicolumn{1}{c|}{$\begin{array}{c}\text { Cronbach's } \\
\text { Alpha }\end{array}$} & \multicolumn{1}{c|}{$\begin{array}{c}\text { Deleting } \\
\text { Item }\end{array}$} & $\begin{array}{c}\text { Cronbach's } \\
\text { Alpha } \\
\text { removing } \\
\text { the Item }\end{array}$ \\
\hline X1 Resources & .783 & 1 & .801 \\
\hline $\begin{array}{l}\text { X2 } \\
\text { Transformational } \\
\text { Leadership }\end{array}$ & .853 & 2 & .887 \\
\hline $\begin{array}{l}\text { Y. Strategic } \\
\text { Management }\end{array}$ & .883 & 2 & .887 \\
\hline
\end{tabular}

Table 4 Cronbach Alpha concentrate per construct in the pilot test

Source: own elaboration Data obtained from the Basic System SPSS Statistics, version 21

The cronbach alphas can be seen in table 4 , which are above 6 , so it follows that the questions that are part of a construct are independent of each other, there is no correlation. (Oviedo and Campos, 2005). The results with respect to the demographic analysis of the profile of the respondent is as follows: the companies are newly created by $46 \%$ and are 1 to 3 years old. The interviewees who represent themselves as the person who has the highest level for decisionmaking in the company, has a bachelor's degree at $49 \%$, and with $52 \%$ the women are represented who are the ones who administer the majority to the companies surveyed.
Results of the statistical analysis through the PLS-SEM, the following table shows the statistical tests of the study.

Evaluation of the reflective measurement model

1. Internal Consistency (Cronbach's alpha, composite reliability)

2. Convergent validity (reliability of the indicator and the average variance extracted (AVE)

3. Discriminant Validity

4. R2 coefficient

Table 5 Evaluation of PLS-SEM (statistical tests) Source: Hair, et al (2017). Adapted format of Martínez and Fierro (2018).

First Validity and Reliability Stage, of the 140 companies evaluated.

\begin{tabular}{|l|c|c|c|}
\hline \multicolumn{2}{|c|}{$\begin{array}{c}\text { Cronbach's } \\
\text { alpha }\end{array}$} & $\begin{array}{c}\text { Composite } \\
\text { reliability }\end{array}$ & $\begin{array}{c}\text { Mean } \\
\text { extracted } \\
\text { variance } \\
\text { (AVE) }\end{array}$ \\
\hline $\begin{array}{l}\text { X1 Resources and } \\
\text { Capabilities }\end{array}$ & 0.811 & 0.864 & 0.515 \\
\hline $\begin{array}{l}\text { X2 } \\
\text { Transformational } \\
\text { Leadership }\end{array}$ & 0.889 & 0.911 & 0.562 \\
\hline $\begin{array}{l}\text { Y. Strategic } \\
\text { Management }\end{array}$ & 0.898 & 0.915 & 0.473 \\
\hline
\end{tabular}

Table 6 Results of cronbach's alpha analysis Source: own elaboration, adapted from the data obtained from the SMART-PLS statistical system. (Structural Equations)

The indicators that are part of a latent variable are measured through composite reliability, since it is more accurate than cronbach's alpha (Nunnally and Bernstein, 1994), less than .60 is considered low reliability, according to the results of the Table 3, the reliability is strong. In the same way it can be evaluated that the Strategic Management variable does not explain more than $50 \%$, this means that the degree of validity is only $47 \%$, its variance in the construct is not explained through its indicators. (Fornell and Larker, 1981).

\begin{tabular}{|c|c|c|c|}
\hline & $\begin{array}{c}\text { Strategic } \\
\text { management }\end{array}$ & $\begin{array}{c}\text { Transformational } \\
\text { Leadership }\end{array}$ & $\begin{array}{l}\text { Resources } \\
\text { and } \\
\text { Capabilities }\end{array}$ \\
\hline $1 \mathrm{~F}$ & 0.744 & & \\
\hline $2 \mathrm{~F}$ & 0.761 & & \\
\hline $3 \mathrm{~F}$ & 0.699 & & \\
\hline $4 \mathrm{~F}$ & 0.560 & & \\
\hline $5 \mathrm{~F}$ & 0.710 & & \\
\hline $6 \mathrm{~F}$ & 0.707 & & \\
\hline $7 \mathrm{I}$ & 0.694 & & \\
\hline $8 \mathrm{I}$ & 0.614 & & \\
\hline $10 \mathrm{I}$ & 0.594 & & \\
\hline $11 \mathrm{I}$ & 0.649 & & \\
\hline $12 \mathrm{e}$ & 0.750 & & \\
\hline
\end{tabular}

LEYVA-OSUNA, Beatriz Alicia, JACOBO-HERNANDEZ, Carlos Armando and AGUIRRE-CHOIX, Ricardo. Impact of Resources and Transformational Leadership in the Strategic Management of Small Business Enterprises. ECORFAN Journal-Republic of Peru. 2019 


\begin{tabular}{|l|l|l|l|}
\hline $13 \mathrm{e}$ & 0.691 & & \\
\hline $14 \mathrm{e}$ & 0.742 & & \\
\hline $18 \mathrm{rc}$ & & & 0.694 \\
\hline $19 \mathrm{rc}$ & & & 0.764 \\
\hline $20 \mathrm{rc}$ & & & 0.764 \\
\hline $21 \mathrm{rc}$ & & & 0.717 \\
\hline $22 \mathrm{rc}$ & & & 0.604 \\
\hline $23 \mathrm{rc}$ & & & 0.750 \\
\hline $24 \mathrm{Lt}$ & & 0.706 & \\
\hline $25 \mathrm{Lt}$ & & 0.801 & \\
\hline $26 \mathrm{Lt}$ & & 0.758 & \\
\hline $27 \mathrm{Lt}$ & & 0.714 & \\
\hline $28 \mathrm{Lt}$ & & 0.712 & \\
\hline $29 \mathrm{Lt}$ & & 0.742 & \\
\hline $30 \mathrm{Lt}$ & & 0.786 & \\
\hline $31 \mathrm{Lt}$ & & & \\
\hline
\end{tabular}

Table 7 Results of the measurement analysis: loads Source: own elaboration, adapted from the data obtained from the statistical system SMART-PLS (Structural Equations)

From the applied questionnaire the loads of each items are obtained, Chin (1998) states that the charges that are below .5 should be eliminated (in this case 6 items are eliminated) where .7 is represented by $68 \%$, and with charges of .6 is represented with $25 \%$, these two are the most outstanding levels of charges per items.

The last validity test will be carried out through discriminant validity within the PLS, in which the result is that the measurement that a construct is different from another in the model to be studied. (Martínez \& Fierro, 2018). In order to carry out this type of validity, two tests will be considered: a) Fornell and Larcker Criteria, b) Cross Load Criteria, which are presented below: Criterion Fornell and Larcker points out that a latent variable does not share more variance with another latent variable, shares more variance with its indicators, its correlations are greater than with others, (Hulland, 1999). Observe data in table 5.

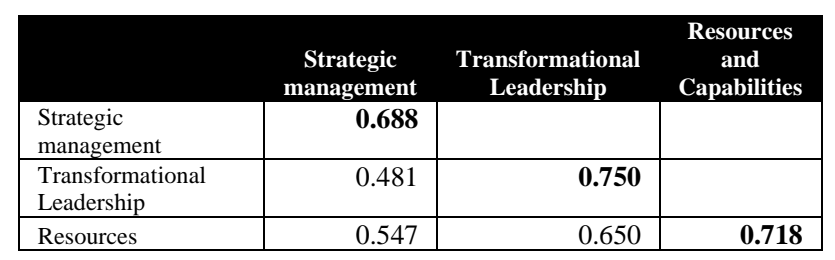

Table 8 Correlation between latent variables (FornellLarcker criteria)

Source: own elaboration, adapted from the data obtained from the SMART-PLS statistical system. (Structural Equations)

This criterion of validity of table 8 is met according to what is stated by (Hulland, 1999).
Cross Loads is the second discriminant validation criterion, Chin (1998) exposes the assumption that the indicator must be greater than its own variable compared to the other variables of the model, as can be seen in Table 9, complying with the results with the criterion of validity.

\begin{tabular}{|l|r|r|r|}
\hline Indicator & $\begin{array}{c}\text { Strategic } \\
\text { management }\end{array}$ & \multicolumn{1}{c}{$\begin{array}{r}\text { Transformational } \\
\text { Leadership }\end{array}$} & $\begin{array}{c}\text { Resources and } \\
\text { Capabilities }\end{array}$ \\
\hline 1f & $\mathbf{0 . 7 4 4}$ & 0.267 & 0.325 \\
\hline 2f & $\mathbf{0 . 7 6 1}$ & 0.261 & 0.423 \\
\hline 3f & $\mathbf{0 . 6 9 9}$ & 0.336 & 0.365 \\
\hline 4f & $\mathbf{0 . 5 6 0}$ & 0.207 & 0.215 \\
\hline 5f & $\mathbf{0 . 7 1 0}$ & 0.265 & 0.281 \\
\hline 7I & $\mathbf{0 . 7 0 7}$ & 0.352 & 0.353 \\
\hline 8I & $\mathbf{0 . 6 1 4}$ & 0.388 & 0.394 \\
\hline 10I & $\mathbf{0 . 5 9 4}$ & 0.342 & 0.433 \\
\hline 11I & $\mathbf{0 . 6 4 9}$ & 0.329 & 0.462 \\
\hline 12e & $\mathbf{0 . 7 5 0}$ & 0.398 & 0.474 \\
\hline 13e & $\mathbf{0 . 6 9 1}$ & 0.342 & 0.405 \\
\hline 14e & $\mathbf{0 . 7 4 2}$ & 0.452 & 0.395 \\
\hline 18rc & 0.431 & 0.329 & $\mathbf{0 . 6 9 4}$ \\
\hline 19rc & 0.493 & 0.429 & $\mathbf{0 . 7 6 4}$ \\
\hline 20rc & 0.356 & 0.620 & $\mathbf{0 . 7 6 4}$ \\
\hline 21rc & 0.398 & 0.458 & $\mathbf{0 . 7 1 7}$ \\
\hline 22rc & 0.237 & 0.341 & $\mathbf{0 . 6 0 4}$ \\
\hline 23rc & 0.437 & 0.616 & $\mathbf{0 . 7 5 0}$ \\
\hline 24Lt & 0.320 & $\mathbf{0 . 7 0 6}$ & 0.523 \\
\hline 25Lt & 0.395 & $\mathbf{0 . 8 0 1}$ & 0.545 \\
\hline 26Lt & 0.283 & $\mathbf{0 . 7 5 8}$ & 0.475 \\
\hline 27Lt & 0.292 & $\mathbf{0 . 7 1 4}$ & 0.468 \\
\hline 28Lt & 0.283 & $\mathbf{0 . 7 1 2}$ & 0.519 \\
\hline 29Lt & 0.372 & $\mathbf{0 . 7 4 2}$ & 0.430 \\
\hline 30Lt & 0.413 & $\mathbf{0 . 7 8 6}$ & 0.486 \\
\hline 31Lt & 0.465 & $\mathbf{0 . 7 7 1}$ & 0.505 \\
\hline & & & \\
\hline & & & \\
\hline
\end{tabular}

Table 9 Cross Loads

Source: adapted from the data obtained from the SMARTPLS statistical system. (Structural Equations).

To verify both the reliability and the validity of the instrument, it can be concluded according to these tests that were performed within the outer model, of the structural equations program PLS, the questionnaire is statistically valid and reliable through the measurement of latent variables.

Second Stage Evaluation of the Structural Model Component of the Structural Model (inner model). According to Henseler et al. (2009), this model tries to explain the relationships between latent variables, likewise $\mathrm{R} 2$ is the important coefficient that determines the structural evaluation of the model to analyze. 


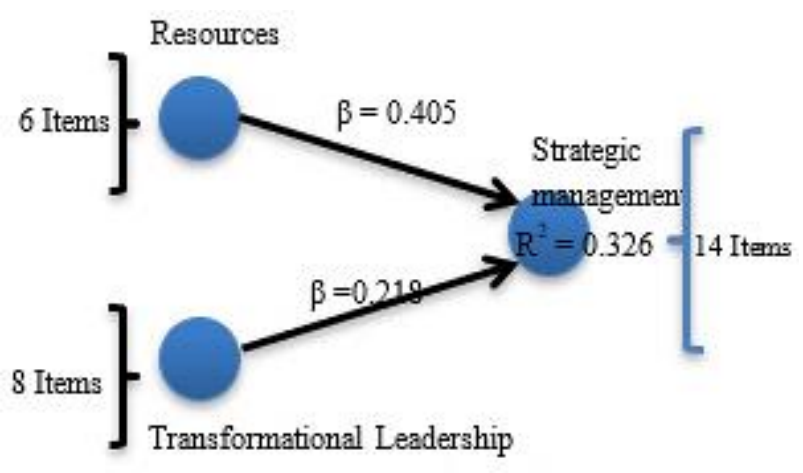

Figure 2 Model of Structural Equations. (Calculation Algorithm of SMART-PLS.)

\begin{tabular}{|l|rr|}
\hline \multicolumn{2}{|c|}{ Variables } & $\mathbf{R}^{2}$ \\
\hline Strategic management & 0.326 \\
\hline
\end{tabular}

Table 10 Results of the $\mathrm{R}^{2}$

Source: adapted from the data obtained from the SMARTPLS statistical system. (Structural Equations)

The ranges for $\mathrm{R}^{2}$ according to Hair et al. (2017) range from $0.75, \quad 0.50$ and 0.25 (substantial, moderate and weak, correspondingly). Chin (1998) describes ranges of $0.67,0.33$ and 0.10 as substantial, moderate and weak. For Falk and Miller (1992), cited by Martínez and Fierro (2018), the minimum value for $\mathrm{R}^{2}$ is 0.10 in the social sciences. According to the information in table 10 , the results of the $\mathrm{R}^{2}$, state that the dependent variable (Y) (endogenous) Strategic Management is explained with $32 \%$ by the independent (exogenous) Resources and Transformational Leadership variables, which according Chin (1998) is considered a weak effect. Next, for the hypothesis test, the calculation of 5000 bootstrapping-PLS interactions was performed, replacing the original sample of 140 observations in this investigation, this calculation determines the standard error and allows the hypothesis test. The calculated sample represents the population (Henseler et al., 2009).

\begin{tabular}{|c|c|c|c|c|}
\hline & $\beta$ & t Student & $\begin{array}{c}\mathbf{P} \\
\text { Value }\end{array}$ & Result \\
\hline $\begin{array}{l}\text { H1. Resources have } \\
\text { a positive and } \\
\text { direct effect on } \\
\text { Strategic } \\
\text { Management. }\end{array}$ & 0.405 & 3.713 & 0.000 & $\begin{array}{l}\text { Accepted } \\
\text { With a } \\
\text { strong } \beta \\
\text { impact and } \\
\text { highly } \\
\text { significant } \\
\text { p-value. }\end{array}$ \\
\hline $\begin{array}{l}\mathrm{H} 2 . \\
\text { Transformational } \\
\text { Leadership has an } \\
\text { effect: Positive and } \\
\text { Direct in Strategic } \\
\text { Management. }\end{array}$ & 0.218 & 1.697 & 0.090 & $\begin{array}{l}\text { It is rejected } \\
\beta \text { important } \\
\text { but the p- } \\
\text { value n.s. }\end{array}$ \\
\hline
\end{tabular}

Table 11 Hypothesis testing

Source: own elaboration, to obtain results of $\beta, T$ Student and P Value, the PLS-SEM software was used
According to Table 11, it is considered that there is a level of interrelation between the variables considered acceptable in the case of Transformational Leadership and Strategic Management and highly acceptable in the relationship of Resources with Strategic Management. (Chin, 1998). Likewise, another statistical test that helps us to analyze the hypothesis test is the T-Student, which indicates the impact of the independent variables on the dependent and the $\mathrm{P}$ value, shows the level of statistical significance of each of the betas in the relationships of the variables. (Rositas, 2014). The results in these calculations show that the TStudent is considered acceptable since they are less than 5\% error, however the results in the $\mathrm{P}$ value are not met in the relationship of Transformational Leadership and Strategic Management since it is for above (0.090) of the acceptable minimum ( $\mathrm{p}<=.05)$. (Rositas, 2014).

\section{Conclusions}

This section presents the achievements, findings and interpretations of the statistical and theoretical results. The dependent variable Strategic Management is explained with $30 \%$ by the variables of Resources and Transformational Leadership. The equation dependent on Strategic Management is:

$$
\mathrm{GE}(\mathrm{Y})=\mathrm{f}(\beta 0.405(\mathrm{RC}))+(\beta 0.218(\mathrm{LT}))
$$

According to the results for hypothesis 1 , the Resources variable has a direct impact on Strategic Management. According to the results in the model, it is confirmed that these relationships have a positive, direct and highly significant effect $(\beta .405, \mathrm{p}<=.000)$.

The results obtained statistically in this study are supported in a toric way. Mintzberg, Quinn and Voyer (1997) emphasize that a strategy that is formulated efficiently puts order in its execution, appropriately allocating the organization's resources according to its attributes and deficiencies in the company; in order to achieve a viable and original situation and allow the scope of the aforementioned strategy.

The SMEs must effectively and efficiently attend to all their resources, such as technological resources that, through them, seek to improve their facilities and allow for better operational and market development. 
Another resources to take care of in the SMEs is the financial one, in which its planning must be taken care of so as not to fall into lack of liquidity, and it can be one of many causes of business closure. And finally the human resource, this is considered within companies as the main cause of business failure. (Rubio and Aragón, 2006)

Before a company decides to manage a strategy and deal with the competition, it must ensure an internal analysis and assess whether it has the necessary resources to compete and launch an effective strategy. Monfort (2002).

In the results of hypothesis 2, Transformational Leadership has a direct but not significant positive impact with Strategic Management, ( $\beta$.218, $\mathrm{p}<=090$ n.s.). According to the results this hypothesis is rejected. According to results in their empirical research Rodríguez, Pedraja, Delgado and Rodríguez (2010), conclude with reference to the transformational leadership that does not significantly impact the quality of the strategy design ( $p<0.569$ ), however the quality of the design of The strategy positively impacts the quality of the strategy implementation, ( $p$ $<0.000)$.

The authors Pedraja, Rodríguez, and Rodríguez, (2006) state that with respect to their leadership relationships with the strategy there is no integrative model in the field of strategic management regarding the relationship between leadership-decision-making effectiveness, (Performance).

Currently the mentality of the entrepreneur of these companies SMEs Comerciales in Ciudad Obregón, expresses the little importance that he gives to the strategic management process in his company; since no important results are obtained. However, the idea of some of its human resources is strengthened, it is considered the engine of the same, that the operational, administrative and strategic areas depend on them, since the Transformational Leadership variable impacts within the stages of Strategic Management, as well as in the Organizational Performance of the same.
It is suggested as future research, to analyze the situation of the companies of other turns to complement the results, such as SMEs companies of industrial and services, individually (by turns), as well as to include in future investigations other factors of more specific studies as for example, within the human resources, the culture and structure of the company, for the purposes of this research were not included.

\section{References}

Arana, D. (2018). SMEs mexicanas, un panorama para 2018.FORBES México. Recuperado de: https://www.forbes.com.mx/SMEs-mexicanasun-panorama-para-2018/

Arbelo, A. y Pérez P. (Enero de 2001). La reputación empresarial como recurso estratégico: un enfoque de recursos y capacidades. En XI Congreso Nacional de $A C A D E$. Recuperado de: http://www.pymesonline.com/uploads/tx_ictico ntent/reputacion.pdf

Bernal, J. (2001). Liderar el Cambio: El Liderazgo Transformacional. Recuperado del sitio web el Departamento de Ciencias de la Educación de la Universidad de Zaragoza de España, de: http://didac.unizar.es/jlbernal/articulos_propios/ pdf/02_lidtrans.PDF

Bernal Torres, C. (2006). Metodología de la Investigación. México: Editorial PEARSON.

Bernal, C. (2010). Metodología de la Investigación. Administración, economía, humanidades $y \quad$ ciencias sociales. México:Prentice Hall.

Burns, J. (2003). Transforming Leadership: A New Pursuit of Happiness. New York, United States of America: Grove Press. Recuperado de: https://books.google.com.mx/books?hl=es\&lr= $\& \mathrm{id}=\mathrm{d} 5 \mathrm{r} 6 \mathrm{dul} 15 \mathrm{Mv} 0 \mathrm{C} \& \mathrm{oi}=$ fnd $\& \mathrm{pg}=\mathrm{PA} 1 \& \mathrm{dq}=\mathrm{bu}$ rns+2003+transforming+leadership\&ots=AGrw OuKc09\&sig=bPIIy08ZCOOkHjn4i3P0WwaC H7Y\#v=onepage\&q=burns\%202003\%20transf orming\%20leadership \&f=false 
Cardona, R. (2013). Estrategia basada en los recursos y capacidades. Criterios de evaluación y el proceso de desarrollo. Revista Forum Doctoral. 4, 113-147. Recuperado de:

http://publicaciones.eafit.edu.co/index.php/foru m-doctoral/article/view/1754

Chin, W. (1998). The partial least squares approach to structural equation modeling. Modern methods for business research . 295335.

Creswell, John. (2003). Researchdesing: qualitative, quantitative. andmixedmethodsapproaches. California,USA: SAGE PublicationsisepiInternational Educational and Professional Publisher Thousand. Recuperdao de: https://ucalgary.ca/paed/files/paed/2003_creswe 11_a-framework-for-design.pdf

David, F. (2008). Conceptos de administración estratégica. México: Pearson-Prentice Hall.

Diario Oficial de la Federación (2013). Clasificación de las SMEs 2009. Recuperado en: http://dof.gob.mx/nota_detalle. php?codigo $=5328349 \&$ fecha $=28 / 12 /$

Fernández, N. (2006). Política, planeamiento y gestión de la educación, Argentina: UNTREF.

Fornell, C. y Larcker, D. (1981). Evaluating structural equation models with unobservable variables and measurement error. Journal of Marketing Research, 18, 39-50

Hair, J. Anderson, R. Tatham, R. y Black, W. (1999). Análisis Multivariante, Madrid: Prentice-Hall.

Hair, J. F., Hult, G. T. M., Ringle, C. M., and Sarstedt, M. (2017). A Primer on Partial Least Squares Structural Equation Modeling (PLSSEM), 2da Ed., Sage: Thousand Oaks.

Henseler, J. Ringle, C. y Sinkovics, R. (2009). The use of partial least squares path modeling in international marketing. Advances in International Marketing. 20, 277-319.

Hulland, J. (1999). Use of partial least squares (PLS) in strategic management research: a review of four recent studies. Strategic Management Journal, 20, 195-204.
INADEM (2018).Las MiPyME en México: retos y oportunidades. Recuperado de: https://www.inadem.gob.mx/las-mipyme-enmexico-retos-y-oportunidades/

INEGI-DENUE (2012). Directorio de empresas $y$ establecimientos. Recuperado de: http://www.beta.inegi.org.mx/app/mapa/denue/

INEGI (2014). Esperanza de vida de los negocios en México. Recuperado de: http://www.inegi.org.mx/inegi/contenidos/inves tigacion/Experimentales/Esperanza/default.aspx

INEGI (2015). México en cifra: Esperanza de vida en los negocios. Recuperado de: http://www.beta.inegi.org.mx/app/mapa/denue/ default.aspx

Martínez, M. y Fierro, E. (2018).Aplicación de la Técnica PLS-SEM en la gestión del conocimiento: un enfoque teórico practico. Revista Iberoamericana para la investigación y el desarrollo educativo. 8(16), 1-35. Recuperado de:

http://hdl.handle.net/20.500.11799/79994

Monfort, V. (2002). Estrategia competitiva y desempeño en la industria hotelera costera: evidencias empíricas en Benidorm y Peñíscola. Cuadernos de turismo. (10), 7-22.

Nunnally, J. y Bernstein, I. (1994). Psychometric theory. New York: McGraw-Hill.

Oviedo, H. y Campo, A. (2005). Aproximación al uso del coeficiente alfa de Cronbach. Revista Colombiana de Psiquiatría. 34(4), 572-580. Recuperado de: http://www.redalyc.org/pdf/806/80634409.pdf

Pedraja, L. Rodríguez, E. y Rodríguez, J. (2006). Liderazgo y decisiones estratégica: Una perspectiva integradora. Interciencia, 31(8), 577-582. Recuperado de: http://www.redalyc.org/articulo.oa?id=3391190 5

ProMéxico, (2013). SMEs, eslabón, fundamental para el crecimiento en México. Recuperado de: http://www.promexico.gob.mx/negociosinternacionales/SMEs-eslabon-fundamentalpara-el-crecimiento-en-mexico.html. 
Rodríguez, E., Pedraja, L., Delgado, M., y Rodríguez, J. (2010). Gestión del conocimiento, liderazgo, diseño e implementación de la estrategia: Un estudio empírico en pequeñas y medianas empresas. Ingeniare. Revista Chilena de Ingeniería. 18(3), 373-382. Recuperado de: http://www.redalyc.org/pdf/772/77218814011.p df

Rositas, J. (2014). Los tamaños de las muestras en encuestas de las ciencias sociales y su repercusión en la generación del conocimiento. Innovaciones de Negocios.11 (22), 235-268. Recuperado de: http://www.web.facpya.uanl.mx/rev_in/Revista s/11_22/11.22\%20Art4\%20pp\%20235\%20\%20268.pdf

Rubio, A. y Aragón, A. (2006). Competitividad y recursos estratégicos en las SMES. Revista Europea de Dirección y Economía de la Empresa. 17(1), 103-126. Recuperado de: http://www.aedemvirtual.com/articulos/122762873600.pdf

Segovia Romo A. (2014). El liderazgo, la compensación variable, el empowerment psicológico y su impacto en la efectividad del empleado: Un enfoque de modelación mediante ecuaciones estructurales. (Tesis Doctorado Inédita). Universidad Autónoma de Nuevo León. Monterrey, NL. Recuperado de: http://eprints.uanl.mx/3923/1/1080253595.pdf

Tamayo, M. (2004). Proceso de la Investigación Científica. México: Editorial LIMUSA. Recuperado de:

https://books.google.com.mx/books?id=Bhym $\mathrm{mEqkkJwC} \&$ printsec $=$ frontcover $\& \mathrm{dq}=$ metodol ogia+dela+investigacion+tamayo\&hl=es\&sa $=X$ \&ved=0ahUKEwj_yYrUINDQAhVLxmMKHf mdAUYQ6AEIIDAC\#v=onepage $\& \mathrm{q}=$ metodolo gia\%20dela\%20investigacion $\% 20$ tamayo $\& \mathrm{f}=\mathrm{fa}$ lse

Toro, I. y Parra, R. (2006). Método y Conocimiento, Metodología de la Investigación. Colombia: Fondo Editorial Universidad EAFIT. Recuperado de:

https://books.google.com.mx/books?id=4YkHG jEjy0C\&pg=PA158\&dq=investigación+no+exp erimental\&hl=es\&sa $=X \& v e d=0$ ahUKEwiZ8ab XvNDQAhWHqlQKHbTVAwsQ6AEIGDAB\# $\mathrm{v}=$ onepage \& $\mathrm{q}=$ investigación $\% 20 \mathrm{no} \% 20$ experi mental\&f=false
Torres, Z. (2014). Administración Estratégica. México: Grupo Editorial Patria, S.A. de C.V. 